\title{
Pencarian Rumus Perhitungan Jumlah Sampel Minimal yang Digunakan Pada Penelitian Perilaku Perjalanan Terdahulu
}

\author{
Searching for Minimum Number of Sample Formula Used in Previous \\ Travel Behavior Research
}

\author{
Anita Susanti $^{\text {a) }}$, Ria Asih Aryani Soemitro $\left.{ }^{2 b}\right)$, Hitapriya Suprayitno ${ }^{2 c)}$ \\ ${ }^{1)}$ Mahasiswa Teknik Sipil, Institut Teknologi Sepuluh Nopember (ITS), Surabaya. \\ ${ }^{2}$ Departemen Teknik Sipil, Institut Teknologi Sepuluh Nopember (ITS), Surabaya.
}

Koresponden : a)anitasusanti.pasmar@gmail.com, ${ }^{\text {b) }}$ ria@ce.its.ac.id \& ${ }^{\mathrm{c})}$ suprayitno.hita@gmail.com

\begin{abstract}
ABSTRAK
Fasilitas adalah salah satu komponen penting yang harus dikelola dengan baik, ekonomis dan efesien sesuai dengan prinsip-prinsip Manajemen Aset Fasilitas. Perhitungan jumlah sampel minimal sangat dibutuhkan bagi kasus Karakteristik Perilaku Perjalanan. Kasus tersebut seringkali berhubungan dengan jumlah populasi yang sangat besar. Oleh karena itu diperlukan suatu penelitian awal mengenai bentuk-bentuk rumus perhitungan jumlah sampel minimal yang banyak digunakan oleh peneliti terdahulu berdasarkan studi literatur. Tujuan dilakukannya penelitian ini adalah untuk mengetahui ada tidaknya rumus perhitungan jumlah sampel minimal yang digunakan oleh peneliti terdahulu. Apabila rumus tersebut ada, maka dapat diketahui bentuk-bentuk rumus perhitungan jumlah sampel minimal yang digunakan oleh peneliti terdahulu bagi Kasus Proporsi. Metode penelitian dilakukan berdasarkan studi literatur. Hasil penelitian dapat disampaikan beberapa hal penting sebagai berikut: 1). Peneliti terdahulu banyak yang tidak membahas mengenai rumus perhitungan jumlah sampel yang digunakan pada penelitiannya; 2). Peneliti terdahulu banyak yang hanya menuliskan jumlah sampel saja tanpa adanya rumus perhitungan jumlah sampel yang digunakan. Berdasarkan uraian di atas, maka dapat ditarik kesimpulan perlu adanya penelitian lanjutan untuk dapat menemukan Metoda yang Tepat bagi Kasus Penelitian Karakteristik Perilaku Perjalanan berupa Proporsi. Hal tersebut penting untuk dilakukan, mengingat bahwa Kasus Penelitian Karakteristik Perilaku Perjalanan sangat berkaitan dengan jumlah populasi, jumlah surveyor dan biaya yang besar serta waktu pelaksanaan yang cukup lama.
\end{abstract}

Kata Kunci : karakteristik perilaku perjalanan, populasi, rumus jumlah sampel, studi literatur, proporsi

\section{PENDAHULUAN}

Fasilitas adalah salah satu komponen penting yang harus dikelola dengan baik, ekonomis dan efesien sesuai dengan prinsip-prinsip Manajemen Aset Fasilitas. Ketersediaan Fasilitas harus disesuaikan dengan adanya permintaan atau penawaran. Aspek Permintaan-Penawaran yang terdiri dari berbagai macam bentuk dan ukuran yang berbeda tersebut, dapat terjadi pada Fasilitas yang berbeda pula (Soemitro \& Suprayitno, 2018).

Perhitungan jumlah sampel minimal sangat dibutuhkan bagi suatu penelitian. Pada kasus penelitian Karakteristik Perilaku Perjalanan seringkali berhubungan dengan jumlah populasi yang sangat besar. Jumlah populasi yang besar tersebut, tentunya membutuhkan jumlah sampel 
yang cukup baik untuk dapat menggambarkan keadaan populasi yang sebenarnya (Supranto, 2008; Asra \& Prasetyo, 2015; Purwanto \& Sulistyastuti, 2017).

Jumlah sampel pada kasus Karakteristik Perilaku Perjalanan, khususnya yang berupa Proporsi penting untuk diketahui. Penelitian Karakteristik perilaku perjalanan yang diamati adalah Karakteristik Pelaku dan Perilaku Perjalanan. Semakin banyak hal-hal yang diamati, maka semakin besar jumlah sampel yang berdampak pada semakin besar biaya, waktu pelaksanaan dan jumlah tenaga (Supranto, 2008).

Berpijak pada uraian di atas, maka penentuan bentuk rumus perhitungan jumlah sampel minimal merupakan langkah awal yang harus ditentukan terlebih dahulu. Hal tersebut dilakukan untuk menghindari terjadinya kesalahan pada saat perhitungan jumlah sampel minimal. Khususnya jumlah sampel minimal bagi Kasus Penelitian Karakteristik Perilaku Perjalanan berupa Proporsi.

Oleh karena itu diperlukan suatu penelitian awal tentang bentuk-bentuk rumus perhitungan jumlah sampel minimal bagi Kasus Proporsi yang digunakan oleh peneliti terdahulu.

Tujuan dilakukannya penelitian ini adalah untuk mengetahui ada tidaknya rumus perhitungan jumlah sampel minimal yang digunakan oleh peneliti terdahulu. Apabila rumus tersebut ada, maka dapat diketahui bentuk-bentuk rumus perhitungan jumlah sampel minimal yang digunakan oleh peneliti terdahulu bagi Kasus Karakteristik Perilaku Perjalanan berupa Proporsi.

\section{STUDI PUSTAKA}

\section{Definisi Populasi dan Sampel}

Populasi adalah kumpulan seluruh elemen-elemen individu/unit-unit yang menjadi obyek/target penelitian, sedangkan sampel adalah bagian dari populasi (Supranto, 2008; Asra \& Prasetyo, 2015; Purwanto \& Sulistyastuti, 2017).

Sampel dapat dikatakan sampel baik/representative, apabila mampu mempertimbangkan proporsi karakter yang ada pada populasi dan karakteristik sampel sama dengan karakteristik populasi. Apabila karakteristik sampel tidak sama dapat dikatakan sampel tidak baik/unrepresentative sample (Purwanto \& Sulistyastuti, 2017).

\section{Teknik Pengambilan Sampel}

Teknik pengambilan sampel lebih mudah dilakukan pada karakteristik populasi yang sifatnya homogen, dibandingkan dengan populasi yang sifatnya heterogen. Syarat-syarat pengambilan sampel agar diperoleh sampel yang baik/representative (Purwanto \& Sulistyastuti, 2017) adalah sebagai berikut :

- Jumlah sampel, semakin besar jumlah sampel yang diteliti, maka semakin tinggi tingkat kebenarannya/representative. Besar kecilnya jumlah sampel, ditentukan oleh beberapa hal sebagai berikut :

1. Besarnya biaya

2. Waktu dan tenaga

- Teknik pengambilan sampel, semakin tinggi tingkat random pengambilan sampel, maka semakin tinggi pula tingkat representative.

- Ciri-ciri sampel harus dipertimbangkan pada saat pengambilan sampel dan harus sesuai dengan tujuan penelitian. Semakin lengkap ciri-ciri sampel, maka sampel semakin representative.

Sampel merupakan bagian terpenting bagi suatu penelitian dengan beberapa alasan sebagai berikut: 1). Keterbatasan dana; 2). Keterbatasan waktu dan tenaga; 3). Ukuran populasi sangat besar; 4). Variabel dalam populasi bersifat homogen (Purwanto \& Sulistyastuti, 2017). 


\section{Komposisi Distribusi Proporsi}

Penelitian tentang Karakteristik Perilaku Perjalanan yang diamati adalah Karakteristik Pelaku dan Karakteristik Perilaku Perjalanan.

Karakteristik Pelaku Perjalanan terdiri dari usia, jenis kelamin, pekerjaan, pendidikan. Karakteristik Perilaku Perjalanan terdiri dari maksud perjalanan, kendaraan sebelum, jarak perjalanan hubung Ke-, moda hubung Ke-, jarak perjalanan hubung Dari-, moda perjalanan hubung Dari. Kedua Karakteristik tersebut dipresentasikan ke dalam bentuk Tabel dan Grafik (Suprayitno \& Ryansyah, 2018; Upa, Suprayitno \& Ryansyah, 2018).

Karakteristik Pelaku dan Perilaku Perjalanan mengandung Komposisi Dustribusi Proporsi. Komposisi Proporsi dapat disampaikan dalam bentuk Tabel dan Grafik Kurva Distribusi Proprosi. Hasil presentasi Komposisi Proporsi ke dalam bentuk Tabel dan Grafik sudah pernah dilakukan oleh peneliti terdahulu yaitu Suprayitno \& Ryansyah, 2018; Upa, Suprayitno \& Ryansyah, 2018).

$\underline{\text { Komposisi Distribusi Proporsi Bagi Karakteristik Pelaku Perjalanan }}$

Komposisi distribusi proporsi ditinjau dari Pekerjaan Penumpang Bus Trans Koetaradja didominasi oleh Pegawai sebesar 55\% dan Mahasiswa sebesar 35\%. Jumlah Proporsi tersebut sejumlah 3 yaitu pqr yang ditunjukkan pada Tabel 1 dan Gambar 1 (Suprayitno \& Ryansyah, 2018).

Tabel 1. Komposisi Distribusi Proporsi Pekerjaan Pelaku Perjalanan

\begin{tabular}{clccc}
\hline No. & Pekerjaan & Jumlah & $\boldsymbol{\%}$ & $\begin{array}{c}\text { Komulatif } \\
(\boldsymbol{\%})\end{array}$ \\
\hline 1. & Pegawai & 11 & $55 \%$ & $55 \%$ \\
2. & Mahasiswa & 7 & $35 \%$ & $85 \%$ \\
3. & Ibu RT & 2 & $10 \%$ & $100 \%$ \\
\hline & Jumlah & $\mathbf{2 0}$ & $\mathbf{1 0 0 \%}$ & \\
\hline
\end{tabular}

Sumber: Suprayitno \& Ryansyah, 2018

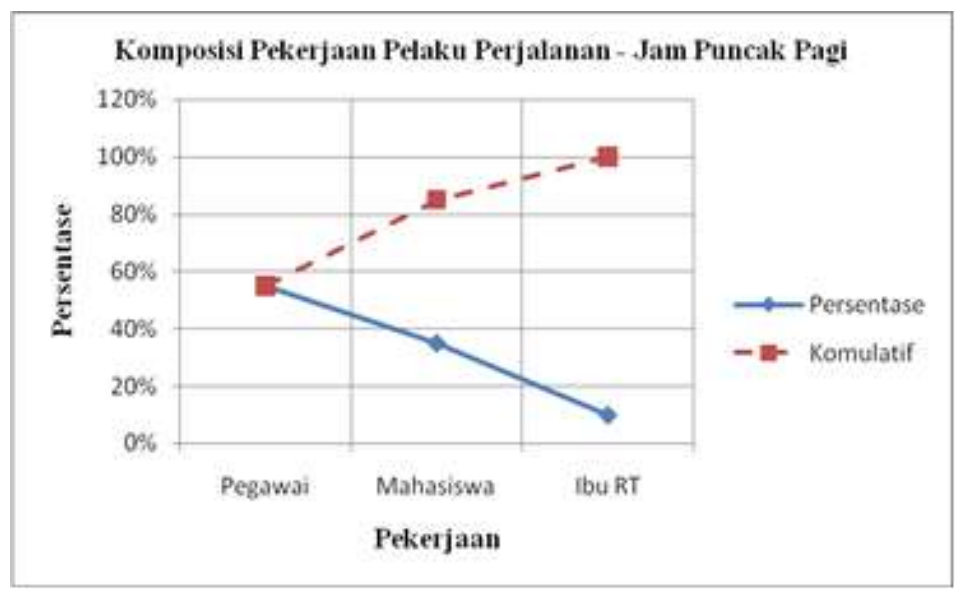

Gambar 1. Grafik Distribusi Proporsi Pekerjaan

$\underline{\text { Komposisi Distribusi Proporsi Bagi Karakteristik Perilaku Perjalanan }}$

Komposisi distribusi ditinjau dari Maksud Perjalanan Penumpang Bus Trans Koetaradja didominasi oleh Bekerja sebesar 55\% dan Belanja sebesar 25\%. Jumlah Proporsi sejumlah 3 yaitu pqr yang ditunjukkan pada Tabel 2 dan Gambar 2 (Suprayitno \& Ryansyah, 2018). 
$\underline{\text { Komposisi Distribusi Proporsi Bagi Karakteristik Perilaku Perjalanan }}$

Komposisi distribusi ditinjau dari Maksud Perjalanan Penumpang Bus Trans Koetaradja didominasi oleh Bekerja sebesar 55\% dan Belanja sebesar 25\%. Jumlah Proporsi sejumlah 3 yaitu pqr yang ditunjukkan pada Tabel 2 dan Gambar 2 (Suprayitno \& Ryansyah, 2018).

Tabel 2. Komposisi Distribusi Proporsi Maksud Perjalanan Pelaku Perjalanan

\begin{tabular}{lllll}
\hline No. & $\begin{array}{l}\text { Maksud } \\
\text { Perjalanan }\end{array}$ & Jumlah & $\mathbf{\%}$ & $\begin{array}{l}\text { Komulatif } \\
(\boldsymbol{\%})\end{array}$ \\
\hline 1. & Bekerja & 11 & $55 \%$ & $55 \%$ \\
2. & Belanja & 5 & $25 \%$ & $80 \%$ \\
3. & Kuliah & 4 & $20 \%$ & $100 \%$ \\
\hline \multicolumn{2}{l}{ Jumlah } & $\mathbf{2 0}$ & $\mathbf{1 0 0 \%}$
\end{tabular}

Sumber: Suprayitno \& Ryansyah, 2018

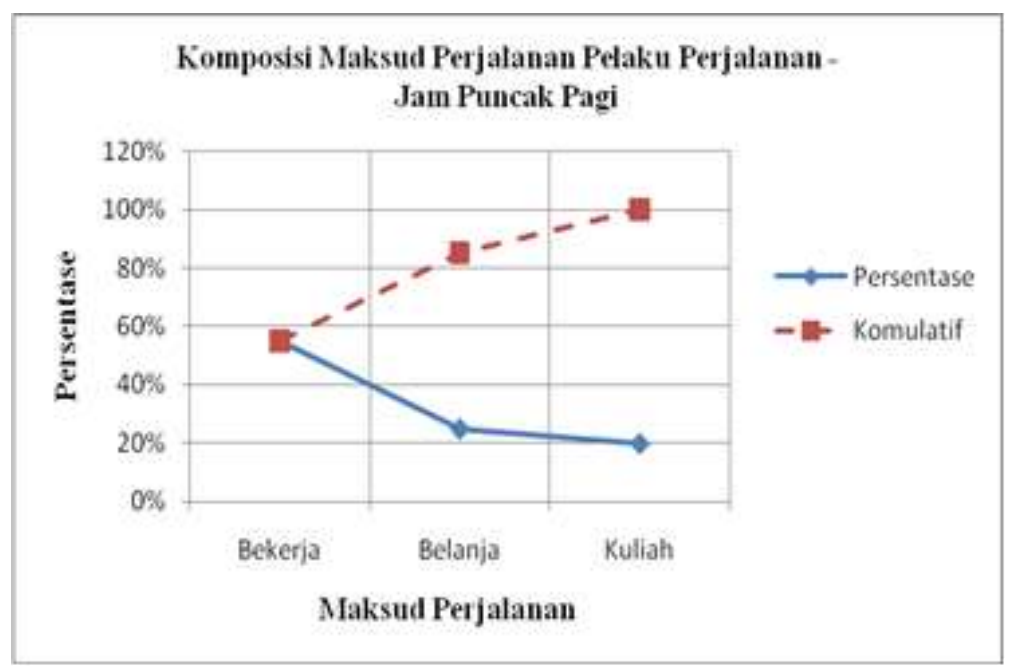

Gambar 2. Grafik Distribusi Proporsi Maksud Perjalanan

\section{METODE PENELITIAN}

Metode yang dilakukan pada penelitian ini adalah studi literatur. Studi literatur diperoleh dari Jurnal Internasional dan Jurnal Nasional. Tujuan dilakukannya penelusuran terhadap beberapa Jurnal tersebut adalah untuk mengetahui bentuk-bentuk rumus perhitungan jumlah sampel minimal yang digunakan oleh peneliti terdahulu terkait dengan Penelitian Karakteristik Perilaku Perjalanan yang berupa Kasus Proporsi. Tahapan pelaksanaan penelitian ditunjukkan pada Gambar 3. 


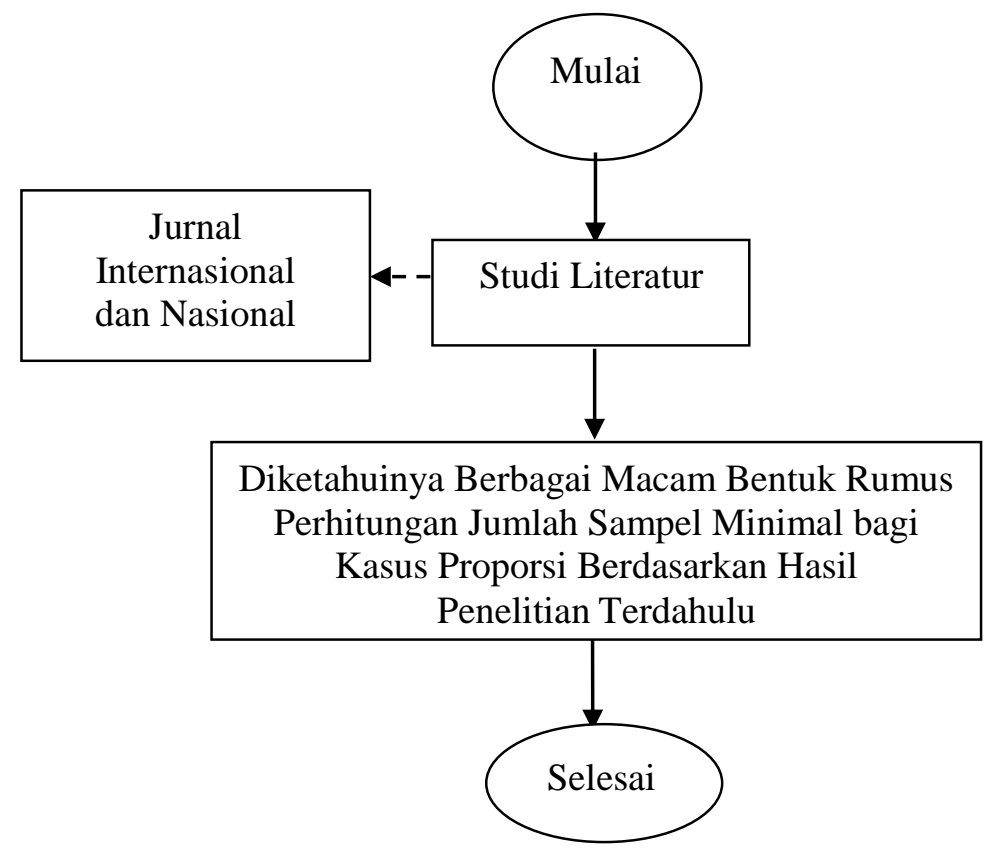

Gambar 3. Bagan Alir Penelitian

\section{ANALISIS DAN PEMBAHASAN}

Pada penelitian ini dilakukan penelusuran terhadap beberapa jurnal internasional dan nasional yang berhubungan dengan kasus karakteristik perilaku perjalanan. Pada beberapa jurnal tersebut dikelompokkan menjadi beberapa topik pembahasan, yaitu: 1). Kelompok Jurnal tentang Topik Perilaku Perjalanan, 2). Kelompok Jurnal tentang Topik KA Komuter, 3). Kelompok Jurnal tentang Topik Jenis Moda Hubung, 4). Kelompok Jurnal tentang Wilayah Pengaruh dan Kebutuhan Fasilitas. Pembagian Topik Pembahasan penelitian tersebut dilakukan untuk mengetahui beberapa hal penting sebagai berikut, yaitu: 1). Judul, 2). Penulis dan Tahun, 3). Karakteristik Pelaku Perjalanan, 4). Karakteristik Perilaku Perjalanan, 5). Model Rumus Perhitungan Jumlah Sampel Minimal apabila dibahas dalam penelitian, 6). Jumlah sampel minimal apabila dibahas pada penelitia, 7). Jenis kasus penelitian.

Penelusuran terhadap beberapa jurnal internasional dan nasional tersebut dilakukan dengan tujuan untuk mengetahui dua hal penting yang mendasari dilakukannya penelitian ini. Kedua hal penting tersebut adalah sebagai berikut: 1). Apakah terdapat rumus perhitungan jumlah sampel minimal bagi kasus karakteristik perilaku perjalanan; 2). Bagaimana bentuk rumus perhitungan jumlah sampel minimal yang digunakan oleh peneliti terdahulu, apabila rumus tersebut dibahas pada penelitian? Kedua komponen di atas ditunjukkan pada Tabel 3, Tabel 4, Tabel 5 dan Tabel 6. 

(e)ISSN 2615-1847 (p)ISSN 2615-1839

Jurnal Manajemen Aset Infrastruktur \& Fasilitas - Vol. 2, Sup. 2, Desember 2018

Tabel 3. Bentuk Rumus Perhitungan Jumlah Sampel Minimal yang Berhubungan dengan Topik Perilaku Perjalanan

\begin{tabular}{|c|c|c|c|c|c|c|c|c|}
\hline No. & $\begin{array}{c}\text { Topik } \\
\text { Penelitian }\end{array}$ & Judul & $\begin{array}{l}\text { Penulis dan } \\
\text { Tahun }\end{array}$ & $\begin{array}{l}\text { Karakteristik } \\
\text { Pelaku } \\
\text { Perjalanan }\end{array}$ & $\begin{array}{c}\text { Karakteristik Perilaku } \\
\text { Perjalanan }\end{array}$ & $\begin{array}{c}\text { Rumus } \\
\text { Perhitungan } \\
\text { Jumlah Sampel } \\
\text { Minimal } \\
\end{array}$ & Jumlah Sampel & Kasus \\
\hline 1. & & $\begin{array}{l}\text { An exploration of the } \\
\text { interdependencies between trip } \\
\text { chaining behavior and travel } \\
\text { mode choice }\end{array}$ & Xianyu, 2013 & $\begin{array}{l}\text { Jenis kelamin, usia, } \\
\text { penghasilan, } \\
\text { kepemilikan kendaraan }\end{array}$ & $\begin{array}{l}\text { Maksud perjalanan (bekerja), } \\
\text { moda hubung yang digunakan }\end{array}$ & $\begin{array}{c}\mathrm{X} \\
\text { (Tidak Ada) }\end{array}$ & - & - \\
\hline 2. & & $\begin{array}{l}\text { Inter-city travel behaviour } \\
\text { adaptation to extreme weather } \\
\text { events }\end{array}$ & Lu et al, 2014 & $\begin{array}{l}\text { Usia, penghasilan, } \\
\text { pendidikan, pekerjaan }\end{array}$ & $\begin{array}{l}\text { Pemilihan moda, rute, perubahan } \\
\text { tujuan }\end{array}$ & $\begin{array}{c}\mathrm{X} \\
\text { (Tidak Ada) }\end{array}$ & $\begin{array}{l}\text { - Jumlah sampel wilayah } \\
\text { Pantai }=2.384 \text { orang } \\
\text { - Jumlah sampel wilayah } \\
\text { Pedalaman } 2=1.427 \\
\text { orang }\end{array}$ & - \\
\hline 3. & & $\begin{array}{l}\text { Spatial-temporal distances in } \\
\text { travel intention-behavior }\end{array}$ & Kah et al, 2016 & $\begin{array}{l}\text { Jenis kelamin, usia, } \\
\text { pendidikan, } \\
\text { pendapatan }\end{array}$ & Jarak perjalanan & $\begin{array}{c}\mathrm{X} \\
\text { (Tidak Ada) }\end{array}$ & $\begin{array}{l}\text { - Jumlah sampel } \\
\text { Perjalanan = } 1.103 \text { orang } \\
\text { - Jumlah sampel Bukan } \\
\text { Perjalanan }=1.897 \text { orang }\end{array}$ & - \\
\hline 4. & $\begin{array}{l}\text { Perilaku } \\
\text { Perjalanan } \\
\text { (Travel } \\
\text { Behavior) }\end{array}$ & $\begin{array}{l}\text { Changing travel behavior in } \\
\text { urban China: Evidence from } \\
\text { Nanjing 2008-2011 }\end{array}$ & Feng et al, 2017 & $\begin{array}{l}\text { Jenis kelamin, usia, } \\
\text { pendidikan, status } \\
\text { dalam keluarga, } \\
\text { penghasilan, } \\
\text { kepemilikan kendaraan } \\
\text { pribadi (mobil) }\end{array}$ & $\begin{array}{l}\text { Jarak perjalanan, moda yang } \\
\text { digunakan, waktu tempuh. }\end{array}$ & $\begin{array}{c}\mathrm{X} \\
\text { (Tidak Ada) }\end{array}$ & - & Proporsi \\
\hline 6. & & $\begin{array}{l}\text { Behavioural economics, travel } \\
\text { behavior and environmental- } \\
\text { transport policy }\end{array}$ & $\begin{array}{l}\text { Sierra et al, } \\
2018\end{array}$ & $\begin{array}{l}\text { Pendapatan, } \\
\text { kepemilikan kendaraan }\end{array}$ & $\begin{array}{l}\text { Maksud, waktu, rute dan moda } \\
\text { perjalanan }\end{array}$ & $\begin{array}{c}\mathrm{X} \\
\text { (Tidak Ada) }\end{array}$ & - & - \\
\hline 7. & & $\begin{array}{l}\text { Karakteristik Pelaku dan Perilaku } \\
\text { Perjalanan Penumpang Bus Trans } \\
\text { Koetaradja }\end{array}$ & $\begin{array}{l}\text { Suprayitno, H. } \\
\& \text { Ryansyah, } \\
\text { M, } 2018\end{array}$ & $\begin{array}{l}\text { Umur, jenis kelamin } \\
\text { pendidikan, pekerjaan }\end{array}$ & $\begin{array}{l}\text { Maksud perjalanan, guna lahan } \\
\text { asal, guna lahan tujuan, moda } \\
\text { hubung ke, moda hubung dari, } \\
\text { frekuensi, moda yang digunakan } \\
\text { sebelum }\end{array}$ & $\begin{array}{c}\mathrm{X} \\
\text { (Tidak Ada) }\end{array}$ & $\begin{array}{l}\text { Jumlah sampel Bus } \\
\text { Koetaradja di pagi hari }=20 \\
\text { orang dan di siang hari }=74 \\
\text { orang }\end{array}$ & \\
\hline 8. & & $\begin{array}{lcr}\text { Perbandingan } & \text { dan } & \text { Sintesis } \\
\text { Karakteristik Perilaku } & \text { Perjalanan } \\
\text { Pengguna } & \text { Bis } & \text { Trans } \\
\text { Mamminasata } & \text { dan } & \text { BisTrans } \\
\text { Koetaradja } & & \end{array}$ & $\begin{array}{l}\text { Upa, V.A., } \\
\text { Suprayitno, H. } \\
\text { \& Ryansyah, } \\
\text { M, } 2018\end{array}$ & - & $\begin{array}{l}\text { Maksud perjalanan, penggunaan } \\
\text { moda sebelum, jarak perjalanan } \\
\text { hubung ke, noda perjalanan } \\
\text { hubung ke, jarak perjalanan } \\
\text { hubung dari, moda perjalanan } \\
\text { hubung dari }\end{array}$ & $\begin{array}{c}\mathrm{X} \\
\text { (Tidak Ada) }\end{array}$ & $\begin{array}{l}\text { - Jumlah sampel } \text { BRT } \\
\text { Mamminasata }=\quad 50 \\
\text { orang } \\
\text { - Jumlah sampel Bus } \\
\text { Koetaradja = 20 orang }\end{array}$ & Proporsi \\
\hline
\end{tabular}


(e)ISSN 2615-1847 (p)ISSN 2615-1839

Jurnal Manajemen Aset Infrastruktur \& Fasilitas - Vol. 2, Sup. 2, Desember 2018

Tabel 4. Bentuk Rumus Perhitungan Jumlah Sampel Minimal yang Berhubungan dengan Topik KA Komuter

\begin{tabular}{|c|c|c|c|c|c|c|c|c|}
\hline No. & Topik & Judul & $\begin{array}{c}\text { Penulis dan } \\
\text { Tahun }\end{array}$ & $\begin{array}{c}\text { Karakteristik Pelaku } \\
\text { Perjalanan }\end{array}$ & $\begin{array}{c}\text { Karakteristik Perilaku } \\
\text { Perjalanan }\end{array}$ & $\begin{array}{c}\text { Rumus } \\
\text { Perhitungan } \\
\text { Jumlah Sampel } \\
\text { Minimal } \\
\end{array}$ & $\begin{array}{l}\text { Jumlah } \\
\text { Sampel }\end{array}$ & Kasus \\
\hline 1. & & $\begin{array}{l}\text { Comparing stress of car and } \\
\text { train commuters }\end{array}$ & $\begin{array}{l}\text { Wener et al, } \\
2011\end{array}$ & $\begin{array}{l}\text { Jenis kelamin, usia, } \\
\text { pekerjaan, pendapatan, } \\
\text { kepemilikan kendaraan, } \\
\text { stataus di dalam rumah } \\
\text { tangga }\end{array}$ & $\begin{array}{l}\text { Moda penghubung (KA dan } \\
\text { mobil) }\end{array}$ & $\begin{array}{c}\mathrm{X} \\
\text { (Tidak Ada) }\end{array}$ & - & $\begin{array}{l}\text { Rata- } \\
\text { Rata }\end{array}$ \\
\hline 2. & & $\begin{array}{l}\text { Commuter rail accesbility and } \\
\text { house values: The case of The } \\
\text { Montreal South Shore, } \\
\text { Canada, 1992-2009 }\end{array}$ & $\begin{array}{l}\text { Dube et al, } \\
2013\end{array}$ & - & $\begin{array}{l}\text { Moda yang digunakan, jarak } \\
\text { perjalanan, waktu mengemudi } \\
\text { kendaraan pribadi (mobil) } \\
\text { menuju stasiun KA }\end{array}$ & $\begin{array}{c}X \\
\text { (Tidak Ada) }\end{array}$ & 23.978 orang & $\begin{array}{l}\text { Rata- } \\
\text { Rata }\end{array}$ \\
\hline 3. & & $\begin{array}{l}\text { Evaluation the effect of mobile } \\
\text { information services for public } \\
\text { transportation through the } \\
\text { empirical research on } \\
\text { commuter trains }\end{array}$ & $\begin{array}{l}\text { Matsumoto et } \\
\text { al, } 2015\end{array}$ & $\begin{array}{l}\text { Jenis kelamin, usia, } \\
\text { pekerjaan }\end{array}$ & $\begin{array}{l}\text { Jenis-jenis layanan yang } \\
\text { disediakan oleh layanan KAdan } \\
\text { terhubung dengan ponsel } \\
\text { penumpang KA }\end{array}$ & $\begin{array}{c}\mathrm{X} \\
\text { (Tidak Ada) }\end{array}$ & 29.813 orang & - \\
\hline 4. & $\begin{array}{c}\text { KA Komuter } \\
\text { (Commuter } \\
\text { Train) }\end{array}$ & $\begin{array}{l}\text { Modeling Indian four-wheeler } \\
\text { commuters' travel behavior } \\
\text { concerning fuel efficiency } \\
\text { improvement poli }\end{array}$ & $\begin{array}{l}\text { Menon et al, } \\
2016\end{array}$ & $\begin{array}{l}\text { Jenis kelamin, usia, } \\
\text { pendidikan, pekerjaan, } \\
\text { pendapatan }\end{array}$ & $\begin{array}{l}\text { Konsumsi bahan bakar, } \\
\text { dampaknya, cara mengurangi } \\
\text { emisi, perilaku perjalanan, } \\
\text { peningkatan efesiensi bahan } \\
\text { bakar, kemauan untuk } \\
\text { bepergian, moda hubung }\end{array}$ & $\begin{array}{c}\mathrm{X} \\
\text { (Tidak Ada) }\end{array}$ & 1.017 orang & $\begin{array}{l}\text { Rata- } \\
\text { Rata }\end{array}$ \\
\hline 6. & & $\begin{array}{l}\text { The happy commuter: A } \\
\text { comparison of commuter } \\
\text { satisfaction across modes }\end{array}$ & $\begin{array}{l}\text { Louis et al, } \\
2017\end{array}$ & Jenis kelamin, umur & $\begin{array}{l}\text { Maksud perjalanan, waktu } \\
\text { perjalanan, waktu tunggu, biaya } \\
\text { perjalanan }\end{array}$ & $\begin{array}{c}\mathrm{X} \\
\text { (Tidak Ada) }\end{array}$ & $\begin{array}{l}\text { - Jumlah } \\
\text { sampel-jalan } \\
\text { kaki = } 1.105 \\
\text { orang } \\
\text { - Jumlah } \\
\text { sampel-sepeda } \\
\text { dan mobil = } \\
439 \text { orang }\end{array}$ & $\begin{array}{l}\text { Proposi } \\
\text { dan } \\
\text { Rata- } \\
\text { Rata }\end{array}$ \\
\hline
\end{tabular}



(e)ISSN 2615-1847 (p)ISSN 2615-1839

Jurnal Manajemen Aset Infrastruktur \& Fasilitas - Vol. 2, Sup. 2, Desember 2018

Tabel 5. Bentuk Rumus Perhitungan Jumlah Sampel Minimal yang Berhubungan dengan Topik Jenis-Jenis Moda Hubung

\begin{tabular}{|c|c|c|c|c|c|c|c|c|}
\hline No. & Topik & Judul & $\begin{array}{c}\text { Penulis dan } \\
\text { Tahun }\end{array}$ & $\begin{array}{c}\text { Karakteristik } \\
\text { Pelaku Perjalanan }\end{array}$ & $\begin{array}{c}\text { Karakteristik Perilaku } \\
\text { Perjalanan }\end{array}$ & $\begin{array}{c}\text { Rumus } \\
\text { Perhitungan } \\
\text { Jumlah Sampel } \\
\text { Minimal } \\
\end{array}$ & Jumlah Sampel & Kasus \\
\hline 1. & & $\begin{array}{l}\text { Public } \quad \text { transport } \\
\text { accesbility in } \\
\text { metropolitan areas: A } \\
\text { new approach } \\
\text { incorporating } \\
\text { population density }\end{array}$ & $\begin{array}{l}\text { Saghapour et } \\
\text { al, } 2016\end{array}$ & - & $\begin{array}{l}\text { Waktu perjalanan, waktu } \\
\text { tunggu, moda yang } \\
\text { digunakan }\end{array}$ & $\begin{array}{c}\mathrm{X} \\
\text { (Tidak Ada) }\end{array}$ & - & $\begin{array}{l}\text { Rata- } \\
\text { Rata dan } \\
\text { Proporsi }\end{array}$ \\
\hline 3. & $\begin{array}{c}\text { Angkutan Umum } \\
\text { (Public } \\
\text { Transport) }\end{array}$ & $\begin{array}{l}\text { Toward the } \\
\text { Development of } \\
\text { Quality Standards for } \\
\text { Public Transport } \\
\text { Service in Developing } \\
\text { Countrirs: Analysis of } \\
\text { Public Transport } \\
\text { Users'Behavior }\end{array}$ & $\begin{array}{l}\text { Ngoc et al, } \\
2017\end{array}$ & - & $\begin{array}{l}\text { Moda hubung, jarak } \\
\text { perjalanan, } \\
\text { perjalanan, waktu tunggu, } \\
\text { biaya perjalanan }\end{array}$ & $\begin{array}{c}\mathrm{X} \\
\text { (Tidak Ada) }\end{array}$ & - & - \\
\hline 4. & & $\begin{array}{l}\text { Reducing dependency } \\
\text { on special transport } \\
\text { services through public } \\
\text { transport }\end{array}$ & $\begin{array}{l}\text { Hansson et } \\
\text { al, } 2017\end{array}$ & $\begin{array}{l}\text { Usia, pendapatan, } \\
\text { kepemilikan } \\
\text { kendaraan }\end{array}$ & $\begin{array}{l}\text { Jarak perjalanan dengan } \\
\text { menggunakan kendaraan, } \\
\text { biaya perjalanan }\end{array}$ & $\begin{array}{c}\mathrm{X} \\
\text { (Tidak Ada) }\end{array}$ & - & - \\
\hline
\end{tabular}


(e)ISSN 2615-1847 (p)ISSN 2615-1839

Jurnal Manajemen Aset Infrastruktur \& Fasilitas - Vol. 2, Sup. 2, Desember 2018

Tabel 6. Bentuk Rumus Perhitungan Jumlah Sampel Minimal yang Berhubungan dengan Topik Jarak Perjalanan Hubung dan Kebutuhan Fasilitas

\begin{tabular}{|c|c|c|c|c|c|c|c|c|}
\hline No. & Topik & Judul & $\begin{array}{l}\text { Penulis dan } \\
\text { Tahun }\end{array}$ & $\begin{array}{c}\text { Karakteristik } \\
\text { Pelaku Perjalanan }\end{array}$ & $\begin{array}{c}\text { Karakteristik Perilaku } \\
\text { Perjalanan }\end{array}$ & $\begin{array}{c}\text { Rumus } \\
\text { Perhitungan } \\
\text { Jumlah Sampel } \\
\text { Minimal }\end{array}$ & Jumlah Sampel & Kasus \\
\hline 1. & & $\begin{array}{l}\text { Mamminasata BRT User Trip } \\
\text { Characteristics for the Design } \\
\text { of Demand Modelling Method } \\
\text { for a New BRT Line }\end{array}$ & $\begin{array}{l}\text { Suprayitno \& Upa, } \\
\quad 2016\end{array}$ & - & $\begin{array}{l}\text { Maksud perjalanan, moda sebelum } \\
\text { beralih, jarak perjalanan hubung } \\
\text { Ke -, moda hubung Ke - jarak } \\
\text { perjalanan hubung Dari -, moda } \\
\text { hubung Dari - }\end{array}$ & $\begin{array}{c}\mathrm{X} \\
\text { (Tidak Ada) }\end{array}$ & $\begin{array}{l}\text { Jumlah sampel } \\
\text { sebesar } 40 \text { orang }\end{array}$ & Proporsi \\
\hline 2. & & $\begin{array}{l}\text { Behavior of Trip Length } \\
\text { Distribution Pattern due to the } \\
\text { Variation of Trip Length } \\
\text { Interval Determination } \\
\end{array}$ & $\begin{array}{c}\text { Suprayitno, H., } \\
\text { Ratnasari, V. \& } \\
\text { Saraswati, N, } 2018 \\
\end{array}$ & - & Jarak perjalanan hubung Ke & $\begin{array}{c}\mathrm{X} \\
\text { (Tidak Ada) }\end{array}$ & $\begin{array}{l}\text { Jumlah sampel } \\
\text { sebesar } 50 \text { orang }\end{array}$ & Proporsi \\
\hline 3. & $\begin{array}{l}\text { Jarak Perjalanan } \\
\text { (Travel Distance) }\end{array}$ & $\begin{array}{lr}\text { Identifikasi Awal } & \text { Wilayah } \\
\text { Pengaruh KA Komuter dengan } \\
\text { Menggunakan } & \text { Angkutan } \\
\text { Umum Pengumpan } & \\
\end{array}$ & $\begin{array}{c}\text { Susanti, A., } \\
\text { Soemitro, R.A.A. } \\
\text { \& Suprayitno, H. } \\
(2018) \\
\end{array}$ & - & $\begin{array}{l}\text { Moda hubung Ke dan Dari, Jarak } \\
\text { perjalanan hubung Ke dan Dari }\end{array}$ & $\begin{array}{c}\mathrm{X} \\
\text { (Tidak Ada) }\end{array}$ & $\begin{array}{c}\text { Jumlah sampel } \\
\text { sebesar } 50 \text { orang dan } \\
57 \text { orang } \\
\end{array}$ & Proporsi \\
\hline 5. & & $\begin{array}{lrr}\text { Identifikasi } & \text { Awal } & \text { Wilayah } \\
\text { Pengaruh Terhadap Pengguna } \\
\text { Sepeda Motor di } & \text { Kota } \\
\text { Surabaya } & & \end{array}$ & $\begin{array}{c}\text { Susanti, A., } \\
\text { Soemitro, R.A.A. } \\
\text { \& Suprayitno, H. } \\
(2018)\end{array}$ & - & $\begin{array}{l}\text { Moda hubung Ke dan Dari, Jarak } \\
\text { perjalanan hubung Ke dan Dari }\end{array}$ & $\begin{array}{c}\mathrm{X} \\
\text { (Tidak Ada) }\end{array}$ & $\begin{array}{l}\text { Jumlah sampel sebesar } \\
50 \text { orang dan } 57 \text { orang }\end{array}$ & Proporsi \\
\hline 6. & & $\begin{array}{llr}\text { Identifikasi } & \text { Awal } & \text { Wilayah } \\
\text { Pengaruh } & \text { Ditinjau } & \text { dari } \\
\begin{array}{l}\text { Penggunaan } \\
\text { Surabaya }\end{array} & \text { Mobil di } & \text { Kota } \\
\end{array}$ & $\begin{array}{c}\text { Susanti, A., } \\
\text { Soemitro, R.A.A. } \\
\text { \& Suprayitno, H. } \\
(2018) \\
\end{array}$ & - & $\begin{array}{l}\text { Moda hubung Ke dan Dari, Jarak } \\
\text { perjalanan hubung Ke dan Dari }\end{array}$ & $\begin{array}{c}\mathrm{X} \\
\text { (Tidak Ada) }\end{array}$ & $\begin{array}{c}\text { Jumlah sampel } \\
\text { sebesar } 50 \text { orang dan } \\
57 \text { orang }\end{array}$ & Proporsi \\
\hline 7. & $\begin{array}{l}\text { Fasilitas } \\
\text { (Facility) }\end{array}$ & $\begin{array}{lr}\text { Identifikasi } & \text { Kebutuhan } \\
\text { Fasilitas Bagi Penumpang di } \\
\text { Stasiun Kereta Api } \\
\text { Berdasarkan } & \text { Analisis } \\
\text { Pergerakan Penumpang }\end{array}$ & $\begin{array}{l}\text { Susanti, A., } \\
\text { Soemitro, R.A.A. } \\
\text { \& Suprayitno, H. } \\
\quad(2018)\end{array}$ & - & $\begin{array}{l}\text { Proses Pergerakan Penumpang KA } \\
\text { dari Lokasi Asal ke Stasiun Asal } \\
\text { dan dari Stasiun Tujuan ke Lokasi } \\
\text { Tujuan }\end{array}$ & $\begin{array}{l}\mathrm{X} \\
\text { (Tidak Ada) }\end{array}$ & - & Proporsi \\
\hline
\end{tabular}





\section{KESIMPULAN}

Penelitian tentang bentuk-bentuk rumus perhitungan jumlah sampel minimal yang banyak digunakan oleh peneliti terdahulu berdasarkan studi literatur, terdapat beberapa hal yang dapat disampaikan sebagai berikut:

- Peneliti terdahulu banyak yang tidak membahas mengenai rumus perhitungan jumlah sampel minimal yang digunakan pada penelitiannya.

- Peneliti terdahulu banyak yang hanya menuliskan jumlah sampel saja tanpa adanya rumus perhitungan jumlah sampel minimal.

Oleh karena itu diperlukan adanya penelitian lanjutan untuk dapat menemukan Metoda Perhitungan Jumlah Sampel Minimal yang Tepat bagi Kasus Karakteristik Perilaku Perjalanan berupa Proporsi.

CATATAN. Penelitian ini dilakukan berdasarkan studi literatur. Tujuan dilakukannya penelitian adalah untuk mengetahui ada tidaknya rumus perhitungan jumlah sampel minimal pada penelitian Karakteristik Perilaku Perjalanan yang sudah dilakukan oleh peneliti terdahulu.

\section{DAFTAR PUSTAKA}

Asra, A. \& Prasetyo A. (2015). Pengambilan Sampel dalam Penelitian Survei. Penerbit PT RAJAGRAFINDO PERSADA, Depok.

Dube, J., Theriault, M., \& Rosiers, F.D. (2013). "Commuter rail accesbility and house values: The case of the Montreal South Shore, Canada, 1992 - 2009”. Transportation Research A 54 (2013), pp. : 49-66.

Engebretsen., Christiansen, P. \& Strand, A. (2017). "Bergen light rail - Effects on travel behavior". Journal of Transport Geography 62 (2017), pp. : 111-121.

Feng, J., Dijst, M., Wissink, B., Prillwitz, J. ( 2017). "Changing travel behavior in urban China: Evidence from Nanjing 2008-2011”. Transport Policy 53 (2017), pp. :1-10.

Gu, Y., Deakin, E., Long, Y. (2017). "The effects of driving restrictions on travel behavior evidence from Beijing”. Journal of Urban Economics 102 (2017), pp. : 106-122.

Hansson, L., \& Holmgren, J. (2017). "Reducing dependency on special transport services through public transport". Transportation Research Procedia 25 (2017), pp. : 2450-2460.

Kah, A.J., Lee, K.C., Lee, H.S. (2016). "Spatial-temporal distances in travel intentionbehavior". Annals of Tourism Research 57(2016), pp. : 160-175.

Louis, E., Manaugh, K., Lierop, D., Geneidy, A.E. (2014). "The happy commuter: A comparison of commuter satisfaction across modes". Transportation Research Part $F 26$ (2014), pp. : 160-170.

Lu, Q.C., Zhang, J., Peng, R.Z., Rahman, A.B.M.Z. (2014). "Inter-city travel behaviour adaptation to extreme weather events". Journal of Transport Geography 41 (2014), pp. : $148-153$.

Matsumoto, T \& Hidaka, K. (2015). "Evaluation the effect of mobile information services for public transportation through the empirical research on commuter trains". Technology in Society 43 (2015), pp. : 144-158.

Menon, B. \& Mahanty, B. (2016). "Modeling Indian four-wheeler commuters' travel behavior concerning fuel efficiency improvement policy". Travel Behaviour and Society 4 (2016), pp. : 11-21.

Ngoc, A.M., Hung, K.V., Tuan, V.A. (2017). “Towards the Development of Quality Standards for Public Transport Service in Developing Countries: Analysis of Public Transport Users Behavior". Transportation Research Procedia 25 (2017), pp. : 4560-4579. 
Purwanto, E.A. \& Sulistyastuti, D.R. (2017). Metode Penelitian Kuantitatif untuk Adiminstrasi Publik dan Masalah-Masalah Sosial Edisi Kedua. Penerbit GAVA MEDIA, Yogyakarta.

Sadhukhan, S., Banerjee, U. \& Maitra, B. (2017). "Preference heterogeneity towards the importance of transfer facility attributes at metro stations in Kolkata". Travel Behaviour and Society (2017), http://dx.doi.org/10.1016/j.tbs.2017.05.001.

Saghapour, T., Moridpour,. \& Thompson, Russel. G. (2016). "Public transport accessibility in metropolitan areas: A new approach incorporating population density". Journal Transport Geography 54 (2016), pp. : 273-285.

Satiennam, T., Jaensisrisak, S., Satiennam, W. \& Detdamrong, S. (2016). "Potensial for Modal Shift by Passenger Car \& Motorcycle Users Towards Bus Rapid Transit (BRT) in an Asian Developing City". IATSS Research 39 (2016), pp. : 121-129.

Sierra, M.G., Bergh, J.C.J.M., Guasch, C.M. (2015). "Behavioural economics, travel behavior and environmental-transport policy". Transportation Research Part D 41 (2018), pp. : 288-305.

Soemitro, R.A.A. \& Suprayitno, H. (2018). "Pemikiran Awal tentang Konsep Dasar Manajemen Aset Fasilitas”. Jurnal Manajemen Aset Infrastruktur \& Fasilitas, Vol. 2, Sup.1, Juni 2018, hal. :1-14.

Supranto. J. (2008). Teknik Sampling untuk Survei \& Eksperimen. Penerbit RINEKA CIPTA, Jakarta.

Suprayitno, H. \& Ryansyah, M. (2018). "Karakteristik Pelaku dan Perilaku Perjalanan Penumpang Bus Trans Koetaradja, Koridor 1: Keudah - Darulsalam". Jurnal Aplikasi Teknik Sipil 16 (2), 2018, hal. :55-62.

Suprayitno, H., Irlambang, D., Pramono, Y.A. \& Wibowo, A.G. (2006). "Karakteristik Penumpang dan Perjalanan Pada KA Penumpang Ekonomi di Wilayah Gerbangkertasusila". Jurnal Teknobisnis, Vol. 2, No. 1, Juli 2006, hal. : 41-48.

Suprayitno, H. \& Upa, V.A. (2016). "Mamminasata BRT User Trip Characteristics for the Design of Demand Modelling Method for a New BRT Line". IPTEK, The Journal for Technology \& Science, Vol. 27, No. 3, December 2016, pp. : 47-52.

Suprayitno, H., Ratnasari, V. \& Saraswati, N. (2018). "Behavior of Trip Length Distribution Pattern due to the Variation of Trip Length Interval Determination". IPTEK, Journal of Engineering, Vol 4, No.1, 2018, pp. : 7-11.

Susanti, A., Soemitro, R.A.A. \& Suprayitno, H. (2017). "Identifikasi Awal Wilayah Pengaruh KA Komuter dengan Menggunakan Angkutan Umum Pengumpan”. Jurnal Rekayasa Sipil, Vol. 11, No. 3, 2017, hal. : 178-185.

Susanti, A., Soemitro, R.A.A. \& Suprayitno, H. (2017a). "Wilayah Pengaruh Kereta Api Komuter terhadap Pengguna Sepeda Motor di Kota Surabaya". Jurnal Transportasi, Vol. 17, No. 3,Desember 2017, hal. :235-244..

Susanti, A., Soemitro, R.A.A. \& Suprayitno, H. (2018). "Analysing the Access and Eagress Distances for BRT Trans Mamminasata Makassar and Commuter Train SUSI". Subbmitted \& Presented in CITIES, Surabaya, 24 - 25 October 2018.

Susanti, A., Soemitro, R.A.A. \& Suprayitno, H. (2018). "Identifikasi Awal Wilayah Pengaruh Ditinjau dari Penggunaan Mobil di Kota Surabaya". Jurnal Bangunan, Vol. 23, No. 2, Oktober 2018, hal. : 1-10.

Susanti, A., Soemitro, R.A.A. \& Suprayitno, H. (2018). "Identifikasi Kebutuhan Fasilitas Bagi Penumpang di Stasiun Kereta Api Berdasarkan Analisis Pergerakan Penumpang”. Jurnal Manajemen Aset Infrastruktur \& Fasilitas, Vol.2, No. 1, Maret 2018, hal. : 23-33. 
Upa, V.A., Suprayitno, H. \& Rayansyah, M. (2018). "Perbandingan dan Sintesa Karakteristik Perilaku Pengguna Bis Trans Mamminasata dan Bis Trans Koetaradja". Jurnal Manajemen Aset Infrastruktur \& Fasilitas, Vol. 2, No. 2, September 2018, hal. : 69-81.

Wener, R.E. \& Evans, G.W. (2011). "Comparing stress of car and train commuters". Transportation Research Part F 14 (2011), pp. : 111-116.

Xianyu, J. (2013). "An exploration of the interdependencies between trip chaining behavior and travel mode choice". Procedia - Social and Behavioral Sciences 96 (2013), pp. :19671975. 